\title{
Kulturarvens Forskerskole, København
}

\author{
Introduktion
}

Beate Knuth Federspiel

\begin{abstract}
Nordisk Museologi ønsker at synliggøre ph.d. miljøet inden for museologien og tilgrænsende forskningsfelter. Som noget nyt præsenteres derfor fra dette nummer relevante ph.d. projekter. Vi indleder med, at en række stipendiater, der har fulgt kurser ved Kulturarvens Forskerskole under det danske Kulturministerium, præsenterer deres projekter.
\end{abstract}

Kulturarvens Forskerskole blev etableret i december 2003 som en tværinstitutionel konstruktion under det danske Kulturministerium. Forskerskolens overordnede formål er at fremme kulturinstitutionernes forskning i den danske kulturarv og at sikre kulturinstitutionerne varig, høj international kvalitet gennem effektiv forskerrekruttering. Forskerskolen er rammen om et samarbejde mellem 4 sektorforskningsinstitutioner: Nationalmuseet, Satens Museum for Kunst, Det Kongelige Bibliotek og Statsbiblioteket, samt 4 højere uddannelsesinstitutioner under Kulturministeriet: Arkitektskolen i Aarhus, Danmarks Biblioteksskole, Kunstakademiets Arkitektskole og Kunstakademiets Konservatorskole. Siden 2004 indgår desuden Afdelingen for Etnologi og Arkæologi, under Saxoinstituttet, Københavns Universitet, i samarbejdet.

Som en del af opfyldelsen af formålet har forskerskolen siden efteråret 2004 udbudt en række kurser, seminarer og workshops, som har det tilfælles, at de søger at skabe en systematisk, tværvidenskabelig forskeruddannelse på kulturarvsområdet. Det er desuden en bestræbelse at fremme de ofte små og meget forskellige forskningsmiljøer ved ABM-institutionerne og kulturuddannelserne og kontakten på tværs af traditionelle faggrænser og institutioner.

I det forløbne års kurser har deltaget stipendiater, som repræsenterer et bredt spektrum af kulturforskning - fra projekter, som retter sig imod den arkitektoniske kulturarv, over kulturmiljø, kirkearkæologi, tværbaltiske kulturog handelsforbindelser, runologi, dragt- og kropskultur, design og mode, bibliotekter som kulturarv, til dokumentarfilm - for blot at nævne et par eksempler. Forskerskolens kurser søges også af andre studerende end dem, der 
96 er tilknyttet de institutioner, der indgår i samarbejdet. For orientering om de kurser, der har været udbudt ved Kulturarvens Forskerskole henvises til: www.db.dk/kaf.

I dette nummer præsenteres projekter af en dansk, en norsk og en islandsk ph.d.studerende. Geografisk er Norden således bredt repræsenteret. Tematisk fordeler projekterne sig mellem arkitekturforskning, konserveringsvidenskab/antropologi og medievidenskab, og repræsenterer således et bredt spektrum af kulturforskningen.

Følgende stipendiater præsenterer deres ph.d. projekter i dette nummer af Nordisk museologi:

Mag.art. Rikke Stenbro, Institut for Arkitektonisk Kulturarv, Arkitekskolen i Aarhus: Transform møde mellem fortidig form og fremtidig anvendelse. Den arkitektoniske kulturarvs forandringsprocesser $i$ det museologiserede samfund gamle og nye parametre for 'heritage production' Cand.scient.cons. Torunn Klokkerness, Kunstakademiets Konservatorskole og Kulturhistorisk Museum, Universitetet i Oslo: Skinn- og pelsberedning i reindyrkulturer - en sammenligning av samiske og evenkiske metoder. Konserveringsvidenskabelige perspektiver $i$ nedbrytning og bevaring af museumssamlinger av skinn og pels

Bjarki Valtysson, Institut for Kommunikation, journalistik og medier, Roskilde Universitets Center: Mapping the Future Cultural Policy of the European Union - The Intersection of Digital Communication, New Media and Progressive Cultural Politics.

Beate Knuth Federspiel, lektor, Kunstakademiets Konservatorskole, studiekoordinator Kulturarvens Forskerskole. E-mail: bkf@kons.dk 